Original Research Paper

\title{
Utilization of plants as food source from Sebaju village forest, Nanga Kebebu village, Nanga Pinoh District, Melawi Regency
}

\author{
Farah Diba $^{1 *}$, Muhammad Sholihin ${ }^{1}$, Nurhaida $^{1}$ \\ ${ }^{1}$ Fakultas Kehutanan Universitas Tanjungpura, Pontianak, Indonesia
}

\author{
Article History \\ Received : December $29^{\text {th }}, 2020$ \\ Revised : January $04^{\text {th }}, 2021$ \\ Accepted : January $16^{\text {th }}, 2021$ \\ Published : January $20^{\text {th }}, 2021$ \\ *Corresponding Author: \\ Farah Diba \\ Fakultas Kehutanan Universitas \\ Tanjungpura Pontianak, Indonesia \\ Email: \\ farahdiba@fahutan.untan.ac.id
}

\begin{abstract}
Forests has a role in supporting food security programs. Sebaju Village Forest, Nanga Kebebu Village, Nanga Pinoh District, Melawi Regency is a village forest area that has the potential of non-timber forest product, one of which is that there are many plants that can be used as food for daily living needs. The research objective was to explore local knowledge of the community and to make an inventory of the types of plants used as food by the communities around the Sebaju village forest, Nanga Kebebu village, Melawi regency, as well ass to describe how to uses and process plants that are used as food by the community. The research method was purposive sampling and data collection was carried out by in-depth interviews with the community in Nanga Kebebu village. The data were analyzed descriptive qualitative in order to obtain a systematic and accurate picture. The results found 58 plant species consisting of 31 families, these plants were dominated by the Anacardiaceae family (8 species). Arecaceae and Moraceae (5 species), Sapindaceae, Phyllanthaceae, Myrtaceae, and Fabaceae (3 species), while one other family each has 1-2 species. The most dominant plant habitats were trees with 40 species $(68.96 \%), 8$ types of herbs $(13.79 \%)$, 4 types of shrubs $(6.89 \%)$ and the least were lianas and 3 types of shrubs. $(5.17 \%)$. The part of the plant that was used the most was the fruit, namely 44 species $(75.38 \%), 8$ types of leaves $(13.79 \%)$, while the parts of the plant that were least used were 2 types of tubers $(3.45 \%), 2$ types tubers $(3.45 \%)$, 1 flower $(1.72 \%), 1$ seed $(1.72 \%)$. The largest group of foodstuffs is fruit as much as 40 types (67\%), 12 types of vegetables (20\%), while the lowest is 3 types of drinks (5\%), 3 types of spices (5\%), and 2 tubers type (3\%). The most widely used food crop processing method is directly used 33 types (56.90\%), 10 types of boiled (17.24\%), 6 types of sauteed (10.34\%) and 5 types of chili sauce $(8.62 \%)$, Meanwhile, the least used processing methods were 2 types of frying $(3.45 \%)$ and 2 types of drying $(3.45 \%)$. Based on their growth status, the highest growth was in the wild, consist of 34 species $(59 \%)$, and the lowest was cultivated by 24 species $(41 \%)$ that grew in the Sebaju customary forest area, Nanga Kebebu Village, Nanga Pinoh District, Melawi Regency. Sebaju village forest has high biodiversity as food plant and local knowledge of te community in the use of plants in the forest area makes conservation efforst better because the community strives to be able to make a sustainable management of food from forest.
\end{abstract}

Keywords: Ethnobotany, Food From Forest, Melawi Regency, Sebaju village forest, West Kalimantan Province

\section{Pendahuluan}

Kalimantan Barat memiliki hutan hujan tropis dengan keanekaragaman jenis tumbuhan yang cukup tinggi. Keanekaragaman hayati merupakan aset bangsa yang sangat penting untuk dijaga kelestarian dan pemanfaatannya. Kekayaan keanekaragaman hayati memiliki keterkaitan dengan budaya 
masyarakat setempat. Salah satunya melalui pemanfaatan hasil hutan berupa tumbuhan yang berguna sebagai bahan makanan yang terdapat di sekitar kawasan hutan (Suhanda et al 2017).

Hutan memiliki sumber daya hayati yang beraneka ragam, banyak diantaranya mempunyai potensi untuk dikembangkan menjadi sumber daya ekonomi. Hutan sebagai suatu ekosistem tidak hanya menyimpan sumberdaya alam berupa kayu, tetapi masih banyak potensi hasil hutan bukan kayu (HHBK) yang dapat diambil manfaatnya, salah satunya adalah tumbuhan sumber pangan yang biasa dimanfaatkan oleh masyarakat untuk memenuhi kebutuhan pangan sehari-hari (Sumarlin et al 2015).

Tumbuhan pangan mempunyai peranan yang sangat penting dalam kehidupan manusia terutama bagi masyarakat sekitar hutan, tumbuhan yang berpotensi sebagai bahan pangan merupakan tumbuhan yang memiliki organ atau bagian yang dapat dimanfaatkan untuk dikonsumsi baik dengan cara diolah maupun dimakan langsung. Sumarlin et al (2015) menyatakan pemanfaatan tumbuhan sumber pangan secara langsung maupun tidak langsung mempunyai kaitan dalam upaya pelestarian dan pemanfaatan sumberdaya alam hayati. Kaidah tersebut dapat dilihat dari nilai-nilai yang terkandung dalam aturan adat suatu kelompok masyarakat.

Pemanfaatan tumbuhan sebagai bahan pangan terus berkembang dan meningkat dengan adanya penelitian terkait identifikasi dan pemanfaatan tumbuhan yang berpotensi sebagai bahan pangan. Juliana et al (2013) menemukan 47 jenis tumbuhan yang dimanfaatkan sebagai bahan pangan di Gunung Peramas Desa Pangkalan Buton Kecamatan Sukadana Kabupaten Kayong Utara. Nurhidayah et al (2015) menemukan 33 jenis tumbuhan yang berpotensi sebagai bahan pangan di Desa Sebangun Kecamatan Sebawi Kabupaten Sambas. Wiwik et al (2019) menemukan 94 jenis tumbuhan bahan pangan yang biasa dimanfaatkan oleh masyarakat Desa Goa Boma Kecamatan Monterado Kabupaten Bengkayang. Pemanfaatan tumbuhan sebagai sumber bahan pangan dirasakan masyarakat merupakan cara yang efektif untuk memenuhi kebutuhan pangan karena sangat mudah diperoleh di lingkungan sekitar (Sumarlin et al. 2015). Peraturan Presiden No. 83 Tahun 2006 tentang Dewan Ketahanan Pangan menyatakan Kementerian
Kehutanan adalah salah satu sektor yang turut bertanggung jawab terhadap ketahanan pangan.

Menurut Peraturan Menteri Kehutanan Nomor P.35/Menhut-II/2007 tentang hasil hutan bukan kayu, hasil hutan bukan kayu adalah hasil hutan hayati baik nabati maupun hewani beserta produk turunan dan budidaya kecuali kayu yang berasal dari hutan. Pemanfaatan hasil hutan bukan kayu di Provinsi Kalimantan Barat telah lama dilakukan oleh masyarakat yang tinggal di kawasan sekitar hutan. Salah satunya masyarakat sekitar hutan adat Sebaju Desa Nanga Kebebu Kecamatan Nanga Pinoh Kabupaten Melawi yang memanfaatkan tumbuhan sebagai sumber bahan pangan. Juliana et al (2013) menyebutkan tumbuhan pangan tersebut dapat berupa buah-buahan, sayur-sayuran, dan umbiumbian yang merupakan salah satu kebutuhan pokok bagi manusia. Jenis-jenis tumbuhan sumber pangan banyak terdapat di hutan karena hutan merupakan habitat utama setiap jenis tumbuhan yang tumbuh secara alami.

Masyarakat sekitar hutan adat Sebaju merupakan masyarakat yang memiliki ketergantungan cukup tinggi dengan keberadaan hutan adat tersebut, oleh karena itu masyarakat mengelola dan memanfaatkan hasil hutan untuk memenuhi kebutuhan hidup sehari-hari. Pengelolaan dan pemanfaatan hutan adat ini berdasarkan Surat Keputusan Bupati Melawi Nomor. 660/171 tahun 2019 tentang Pengakuan Masyarakat Hukum Adat Sebaju Desa Nanga Kebebu Kecamatan Nanga Pinoh Kabupaten Melawi. Hutan adat diatur untuk memberikan jaminan kepastian hukum dan keadilan agar pemangku hutan adat mendapat pengakuan, perlindungan dari pemerintah dalam mengelola hutan secara lestari. Kajian mengenai pemanfaatan tumbuhan sebagai bahan pangan yang terdapat di hutan adat Sebaju Desa Nanga Kebebu Kecamatan Nanga Pinoh Kabupaten Melawi perlu dilakukan mengingat keberadaan hutan sangat berperan penting dalam pemenuhan kebutuhan hidup masyarakat sehari-hari. Tujuan penelitian untuk mengeksplorasi pengetahuan lokal masyarakat dan menginventarisasi jenis-jenis tumbuhan yang dimanfaatkan sebagai bahan pangan oleh masyarakat sekitar hutan adat Sebaju Desa Nanga Kebebu Kabupaten Melawi, serta mendeskripsikan cara pemanfaatan serta pengolahan tumbuhan yang dijadikan sebagai bahan pangan oleh masyarakat. Manfaat penelitian untuk menambah pengetahuan 
mengenai jenis-jenis tumbuhan sebagai bahan pangan dan menjadi upaya pelestarian tumbuhan di hutan adat Sebaju.

\section{Bahan dan Metode}

\section{Lokasi dan Waktu Penelitian}

Penelitian dilaksanakan di kawasan hutan adat Sebaju Desa Nanga Kebebu Kecamatan Nanga Pinoh Kabupaten Melawi dengan waktu penelitian Maret - Mei 2020. Obyek penelitian adalah tumbuhan yang dijadikan sebagai bahan pangan oleh masyarakat sekitar hutan adat Sebaju Desa Nanga Kebebu Kecamatan Nanga Pinoh Kabupaten Melawi. Lokasi penelitian disaiikan pada Gambar 1.

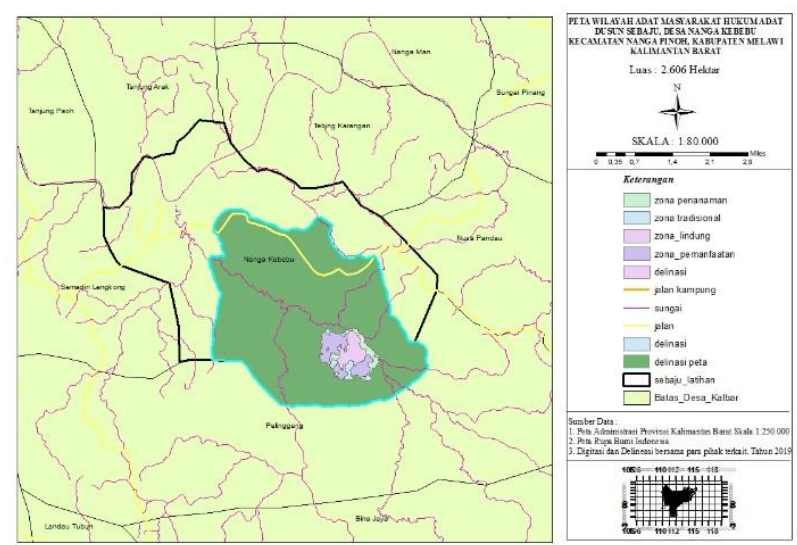

Gambar 1. Lokasi penelitian di Hutan Adat Sebaju Desa Nanga Kebebu Kecamatan Nanga Pinoh Kabupaten Melawi Provinsi Kalimantan Barat

\section{Metode Penelitian}

Penelitian dilakukan dengan metode wawancara mendalam kepada masyarakat Desa Nanga Kebebu Kecamatan Nanga Pinoh Kabupaten Melawi. Data yang dikumpulkan meliputi data primer dan data sekunder. Data primer merupakan data yang diperoleh secara langsung melalui wawancara terhadap responden tentang nama lokal, jenis bahan pangan (buah-buahan, sayur-sayuran, umbi-umbian, bumbu dan minuman), bagian tumbuhan yang digunakan sebagai bahan pangan, dan cara pengolahan sehingga dapat dijadikan sebagai bahan pangan. Selanjutnya dilakukan inventarisasi tumbuhan sebagai bahan pangan di hutan adat Sebaju Desa Nanga Kebebu Kecamatan Nanga Pinoh Kabupaten Melawi Provinsi Kalimantan Barat. Data sekunder adalah studi literatur tentang tumbuhan bahan pangan yang digunakan masyarakat Desa Nanga Kebebu
Kecamatan Nanga Pinoh Kabupaten Melawi Provinsi Kalimantan Barat.

\section{Teknik Pengumpulan Data}

Pengumpulan data dilakukan dengan wawancara mendalam kepada responden untuk mendapatkan informasi tentang pemanfaatan tumbuhan sebagai bahan pangan. Jumlah KK Desa Nanga Kebebu Kecamatan Nanga Pinoh Kabupaten Melawi sebanyak 67 KK. Pemilihan responden menggunakan teknik purposive sampling yaitu teknik pengambilan sampel sumber data dengan pertimbangan tertentu (Sugiyono, 2013). Penelitian menggunakan persentase galat atau ketelitian kesalahan pengambilan sampel yang masih bisa ditoleransi adalah 5\% $(0,05)$ yang dihitung menggunakan rumus Slovin sebagai berikut:

$$
n=\frac{N}{1+N e^{2}}
$$

$n=$ ukuran sampel atau jumlah responden

$N=$ ukuran populasi

$\mathrm{e}=$ derajat kebebasan 5\% $(0,05)$, maka

$$
\begin{aligned}
n & =\frac{N}{1+N e^{2}} \\
& =\frac{67}{1+67(0,05)^{2}}
\end{aligned}
$$

Jumlah responden $=57$ responden

Kriteria masyarakat responden, yaitu:

1) Masyarakat yang tinggal di Dusun Sebaju Desa Nanga Kebebu Kecamatan Nanga Pinoh Kabupaten Melawi

2) Sehat jasmani dan rohani

3) Memiliki pengetahuan mengenai pemanfaatan tumbuhan sebagai bahan pangan

4) Usia minimal 17 tahun

5) Penduduk asli dan penduduk pendatang yang telah menetap di Dusun Sebaju Desa Kebebu Kecamatan Nanga Pinoh Kabupaten Melawi, minimal selama kurang lebih 5 tahun.

Data hasil wawancara tentang pemanfaatan tumbuhan sebagai bahan pangan kemudian dianalisis dengan teknik deskriptif kualitatif sehingga diperoleh gambaran secara sistematis dan akurat. 


\section{Hasil dan Pembahasan}

Tumbuhan sumber pangan yang dimanfaatkan oleh masyarakat Desa Nanga Kebebu Kecamatan

Nanga Pinoh Kabupaten Melawi

Berdasarkan hasil wawancara dengan responden diperoleh 58 spesies tumbuhan yang dimanfaatkan sebagai bahan pangan dan kebutuhan hidup sehari-hari oleh masyarakat sekitar hutan adat Sebaju Desa Nanga Kebebu Kecamatan Nanga Pinoh Kabupaten Melawi. Bagian yang digunakan adalah buah, daun, biji, umbut, dan umbi, sedangkan cara pengolahan untuk dijadikan makanan dengan cara dimakan langsung dan dimasak. Data tumbuhan yang diperoleh meliputi nama lokal, nama latin, famili, habitus, jenis bahan pangan, cara pengolahan dan status tumbuhnya tumbuhan di kawasan hutan adat Sebaju disajikan pada Lampiran 1.

Peran hutan sebagai penyedia bahan pangan sangat besar dan masyarakat di sekitar hutan telah secara turun temurun memanfaatkan tumbuhan dari hutan sebagai sumber pangan (Vinceti et al, 2013). Birgantoro dan Nurrochmat (2007) menyatakan masyarakat di sekitar KPH Banyuwangi Utara memanfaatkan sumberdaya hutan sebagai pangan, yang meliputi buah, daun dan umbi. Rowland et al (2016) melakukan analisis mengenai konsumsi masyarakat terhadap buah, sayur dan hewan, termasuk daging dan ikan, yang berasal dari hutan, sesuai dengan golongan makanan dari FAO. Data sayur yang dikumpulkan termasuk daun, jamur dan umbi-umbian. Hasil penelitian menunjukkan hutan memiliki peran penting sebagai sumber makanan bagi keluarga dan masyarakat yang tinggal di dekat hutan tropis. Masyarakat terbagi menjadi dua kelompok, yaitu kelompok masyarakat bergantung kepada makanan dari hutan dan kelompok masyarakat yang memanfaatkan hutan sebagai suplemen makanan.

Tumbuhan yang digunakan sebagai bahan pangan oleh masyarakat sekitar hutan adat Sebaju Desa Nanga Kebebu Kecamatan Nanga Pinoh Kabupaten Melawi terbagi atas 34 jenis tumbuhan liar dan 24 jenis tumbuhan budidaya. Dasman et al (2015) menemukan 92 jenis tumbuhan yang dimanfaatkan sebagai sumber pangan oleh masyarakat dari kawasan hutan tembawang Nanga Kompi Kecamatan Nanga Sayan Kabupaten Melawi. Jenis tumbuhan yang diperoleh pada penelitian Dasman et al (2015) lebih banyak daripada hasil penelitian ini walaupun berada di lokasi yang sama yaitu di Kabupaten Melawi. Hasil penelitian tersebut menunjukkan keragaman jenis tumbuhan di hutan tembawang Nanga Kompi lebih tinggi daripada hutan adat Sebaju. Masyarakat sekitar hutan adat Sebaju Desa Nanga Kebebu Kecamatan Nanga Pinoh Kabupaten Melawi memanfaatkan tumbuhan seperti buah, sayuran, umbi-umbian, bumbu masakan, dan minuman, sebagai bahan pangan untuk memenuhi kebutuhan hidup sehari-hari.

\section{Famili tumbuhan yang dimanfaatkan sebagai} bahan pangan oleh masyarakat Desa Nanga Kebebu Kecamatan Nanga Pinoh Kabupaten Melawi

Tumbuhan pangan dari hutan adat Sebaju sebanyak 58 jenis dengan jumah famili sebanyak 31 famili. Famili yang mendominasi yaitu famili Anacardiaceae sebanyak 8 spesies, Arecaceae dan Moraceae 5 spesies, Sapindaceae, Phyllanthaceae, Myrtaceae dan Fabaceae 3 spesies, sedangkan famili lainnya masing-masing memiliki 1-2 spesies. Famili Anacardiaceae merupakan famili jenis tumbuhan yang paling banyak dimanfaatkan oleh masyarakat sekitar hutan adat Sebaju, yaitu sebanyak 8 spesies yang semuanya merupakan pohon penghasil buah, meliputi jambu monyet (Anacardium occidentale), kemantan (Mangifera foetida), kedondong (Spondias dulcis), lanyau (Pentaspadon motley Hook), mango (Mangifera indica), semplam (Mangifera sp), sata (Bouea macrophylla Griffith) dan mawang (Mangifera sp). Semua jenis buah tersebut dapat dikonsumsi secara langsung. Famili tumbuhan yang digunakan sebagai bahan pangan oleh masyarakat dari hutan adat Sebaju disajikan pada Gambar 2. 


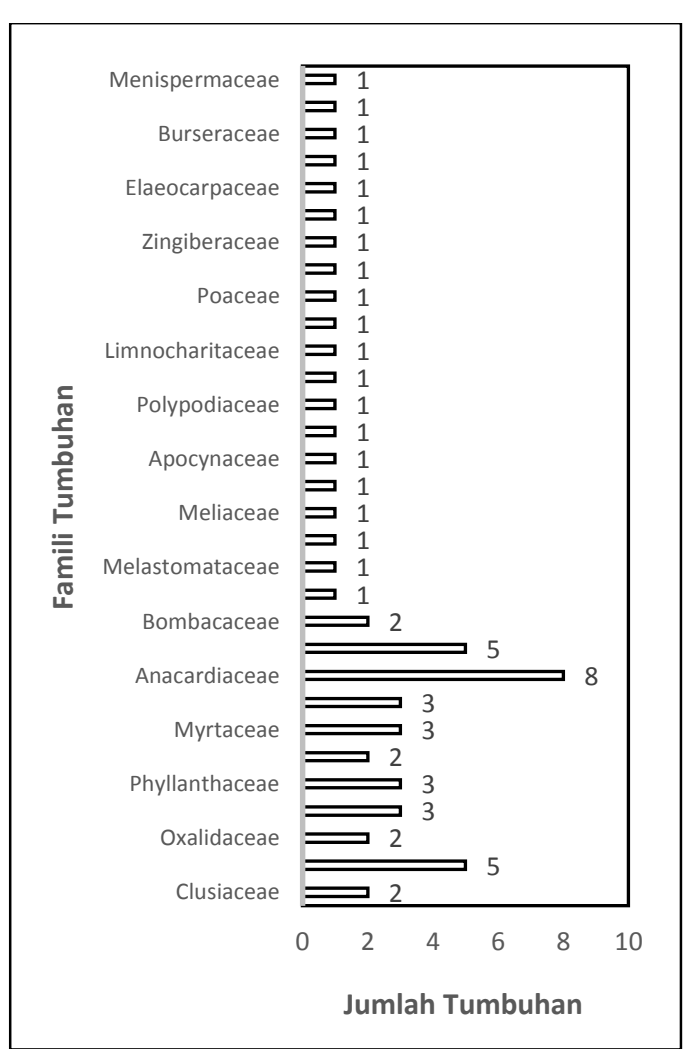

Gambar 2. Famili tumbuhan sebagai bahan pangan dari Hutan Adat Sebaju Desa Nanga Kebebu Kecamatan Nanga Pinoh Kabupaten Melawi Provinsi Kalimantan Barat

Jumlah famili yang ditemukan pada penelitian ini lebih banyak dibandingkan dengan jumlah famili yang ditemukan oleh Juliana et al (2013) yang menemukan 27 famili tumbuhan yang berpotensi sebagai sumber pangan di Gunung Peramas Desa Pangkalan Buton Kecamatan Sukadana Kabupaten Kayong Utara. Penelitian Dasman et al (2015) menemukan 45 famili tumbuhan yang digunakan sebagai bahan pangan oleh masyarakat di sekitar hutan tembawang Nanga Kompi Kecamatan Nanga Sayan Kabupaten Melawi dengan hasil yang sama yaitu famili yang dominan adalah famili Anacardiaceae, Arecaceae dan Moraceae.

Penelitian Wahyuni et al (2017) di kawasan hutan lindung Gunung Pemancing Gunung Ambawang Bukit Bendera Kecamatan Teluk Pakedai Kabupaten Kubu Raya Provinsi Kalimantan Barat menemukan 5 jenis tumbuhan dari famili Anacardiaceae yang merupakan tumbuhan endemik Kalimantan seperti anggur-angguran, langsat hutan, asam bacang, asam kelepah dan nyantoh babi, yang buahnya dapat dikonsumsi langsung oleh masyarakat. Penelitian Toni et al (2017) memperoleh 23 jenis tumbuhan dari tembawang yang digunakan masyarakat di Dusun Toho Raba Desa Rasan Kecamatan Ngabang Kabupaten Landak Provinsi Kalimantan Barat sebagai bahan pangan dengan famili yang mendominasi adalah Moraceae dan Anacardiaceae.

\section{Habitus tumbuhan yang dimanfaatkan sebagai bahan pangan oleh masyarakat Desa Nanga Kebebu Kecamatan Nanga Pinoh Kabupaten Melawi}

Tumbuhan yang dimanfaatkan masyarakat sebagai bahan pangan berdasarkan habitusnya terdiri atas pohon, herba, liana, perdu dan semak. Habitus yang paling banyak dimanfaatkan adalah pohon yaitu sebanyak 40 jenis $(68,96 \%)$, habitus lainnya yang banyak dimanfaatkan yaitu herba 8 jenis $(13,79 \%)$, perdu 4 jenis $(6,89 \%)$ dan yang paling sedikit adalah liana 3 jenis $(5,17 \%)$, dan semak 3 jenis (5,17\%). Rahman et al (2019) menyatakan habitus pohon memiliki bagian atau organ tumbuhan mulai dari akar, batang, buah, bunga, daun dan biji yang dapat digunakan sebagai bahan pangan dan berpotensi menghasilkan bahan-bahan sebagai sumber energi yang tidak berbahaya bagi tubuh. Hasil penelitian menunjukan habitus tingkat pohon lebih tinggi dimanfaatkan oleh masyarakat sekitar hutan adat Sebaju, persaingan dalam ekosistem hutan secara ekologi tingkat pohon dominan pertumbuhannya, dan lebih tinggi tingkat pemanfaatannya jika dibandingkan dengan tingkat habitus lainnya. Habitus pohon sering dijumpai dan banyak terdapat di sekitar lingkungan masyarakat Desa Nanga Kebebu. Tumbuhan berhabitus pohon lebih banyak ditemukan karena jenis tumbuhan pangan yang paling banyak ditemukan yaitu dari jenis buah-buahan, dan hampir semua jenis buahbuahan berasal dari tumbuhan berhabitus pohon. Buah yang dimanfaatkan dari hutan adat Sebaju meliputi pohon mawang yang menghasilkan buah yang dapat dikonsumsi langsung, pohon kelapa yang airnya dapat dijadikan bahan minuman, pohon asam kandis memiliki buah dan daun yang dapat dimanfaatkan sebagai bumbu dapur. Persentase tumbuhan pangan berdasarkan habitus disajikan pada Gambar 3. 


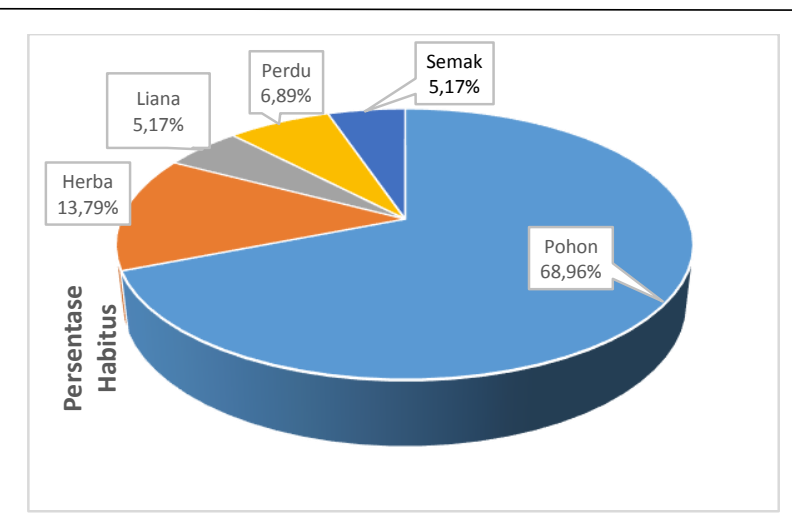

Gambar 3. Habitus tumbuhan sebagai bahan pangan dari Hutan Adat Sebaju Desa Nanga Kebebu Kecamatan Nanga Pinoh Kabupaten Melawi Provinsi Kalimantan Barat

Penelitian ini sejalan dengan penelitian Liza $e t$ al (2020) yang memperoleh 50\% habitus pohon yang dimanfaatkan oleh masyarakat Desa Jawai Laut Kecamatan Jawai Selatan Kabupaten Sambas. Powell et al (2013) menyatakan habitus bahan pangan dari hutan yang paling banyak dimanfaatkan masyarakat adalah pohon yang menghasilkan buah. Hal ini karena buah dapat dimanfaatkan secara langsung dan dapat meningkatkan taraf ekonomi masyarakat dengan menjual buah ke pasar. Tumbuhan yang termasuk dalam habitus herba yang digunakan masyarakat Desa Nanga Kebebu sebagai sumber pangan meliputi genjer (Limnocharis flava), kangkung (Ipomoea aquatica Forsk), asam maram (Eleiodoxa conferta), nenas (Ananas comosus), pisang (Musa paradiasciaca) dan kecombrang (Etlingera elatior).

Tumbuhan yang termasuk dalam habitus semak yang digunakan masyarakat Desa Nanga Kebebu sebagai sumber pangan meliputi pakuk pantai atau pakis hijau (Pletycenum $s p$ ) dan pakuk pidin atau pakis (Stenochlaena palustris). Putri et al (2018) menyatakan tumbuhan paku yang termasuk dalam habitus semak sering digunakan masyarakat sebagai bahan pangan. Deb (2017) menyatakan struktur ekologi hutan berpengaruh terhadap sumber pangan yang dihasilkan. Ekologi hutan tropis didominasi oleh tingkat pohon, kemudian tingkat herba, perdu dan semak. Hal ini menyebabkan sumber pangan dari hutan didominasi oleh habitus pohon.

Bagian tumbuhan yang dimanfaatkan sebagai bahan pangan oleh masyarakat Desa Nanga

\section{Kebebu Kecamatan Nanga Pinoh Kabupaten Melawi}

Bagian tumbuhan yang digunakan sebagai bahan pangan oleh masyarakat sangat bervariasi, mulai dari buah, daun, bunga, biji, umbi dan umbut. Bagian tumbuhan yang paling banyak digunakan adalah buah 44 jenis $(75,86 \%)$, daun 8 jenis $(13,79 \%)$, sedangkan bagian tumbuhan yang paling sedikit digunakan adalah umbut 2 jenis $(3,45 \%)$, umbi 2 jenis $(3,45 \%)$, bunga 1 jenis $(1,72 \%)$, dan biji 1 jenis $(1,72 \%)$. Bagian buah merupakan bagian yang paling banyak digunakan oleh masyarakat sekitar hutan adat Sebaju. Masyarakat Desa Nanga Kebebu menyatakan buah merupakan hasil hutan bukan kayu yang memiliki potensi yang besar sebagai bahan pangan. Pengetahuan jenis buah yang dapat dimakan dari hutan adat Sebaju diperoleh dari pengetahuan orang tua dan dari hasil pengamatan pada buah yang dapat dikonsumsi oleh hewan dan tidak menyebabkan kematian pada hewan tersebut. Pemanfaatan buah dari hutan adat Sebaju tidak menimbulkan pengaruh besar terhadap pertumbuhan pohon dibandingkan dengan pemanfaatan bagian batang atau akar dan tidak berdampak buruk bagi kelangsungan hidup pohon.

Irawan et al (2020) menyatakan bahwa buah memiliki tekstur lunak sehingga mudah untuk diolah. Buah dikonsumsi sebagai bahan pangan karena buah memiliki daging yang umumnya dapat dikonsumsi secara langsung dan dapat diolah dengan cara-cara sederhana. Pradityo (2016) menyatakan masyarakat suku Dayak Iban di Desa Sungai Mawang mengkonsumsi buah sebagai bekal berburu ke hutan, buah mengandung air yang dapat menghilangkan lapar dalam waktu yang singkat bahkan cukup lama ketika melakukan aktifitas berburu. Nurhajijah et al (2017) menyatakan buah mengandung sumber karbohidrat, vitamin dan mineral yang merupakan sumber energi yang dapat menambah tenaga untuk tetap dapat melakukan aktifitas sehari-hari baik aktifitas berat ataupun ringan.

Pemanfaatan bagian tumbuhan dari hutan sebagai sumber pangan dipengaruhi oleh adat istiadat serta budaya masyarakat (Gupta dan Mishra 2014). Masyarakat pedesaan di India umumnya menggunakan buah, daun dan bunga sebagai sumber pangan. Krishnakumar et al (2012) menyatakan hutan menjadi sumber pencarian masyarakat untuk pangan sehari-hari, dengan jenis bagian yang 
digunakan adalah biji, umbi, bunga dan buah. Bagian umbi yang digunakan masyarakat Desa Nanga Kebebu hanya dua jenis dan hasil penelitian ini sejalan dengan penelitian Sunarti et al (2007) di Cagar Alam Tengkale Kecamatan Tibawa Propinsi Gorontalo yang menyatakan masyarakat di sekitar cagar Alam Tengakale sangat sedikit memanfaatkan kelompok umbi-umbian sebagai sumber pangan. Hal ini disebabkan kurangnya pemahaman masyarakat mengenai umbi yang ada di hutan yang dapat dimakan.

Hasil penelitian memperoleh daun yang digunakan oleh masyarakat Desa Nanga Kebebu sebagai sumber pangan meliputi daun buas-buas (Premna serratifolia), daun salam (Syzygium polyanthum), daun ubi (Manihot utilissima), genjer (Limnocharis flava), kangkong (Ipomoea aquatic), mengkudu (Morinda citrifolia), pakuk pantai (Pletycenum sp), pakuk pidin (Stenochlaena palustris) dan daun sengkubak (Pycnarrhena cauliflora Miers). Umbi yang digunakan sebagai sumber pangan oleh masyarakat Desa Nanga Kebebu adalah singkong (Manihot uscelenta) dan keladi (Colocasia esculenta), jenis umbut adalah bambu muda yang disebut masyarakat robong (Bambusa sp) dan rotan muda yang disebut masyarakat ruwok (Calamus rotang), jenis bunga adalah kecombrang yang disebut masyarakat sibong (Etlingera elatior) dan jenis biji adalah petai (Parkia speciosa). Persentase bagian tumbuhan yang digunakan sebagai sumber pangan dari hutan adat Sebaju disajikan pada Gambar 4.

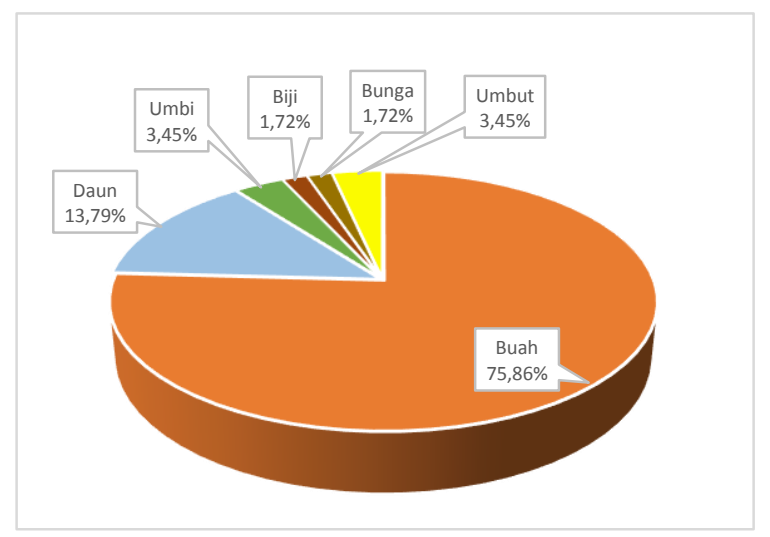

Gambar 4. Bagian tumbuhan yang digunakan sebagai bahan pangan dari Hutan Adat Sebaju Desa Nanga Kebebu Kecamatan Nanga Pinoh Kabupaten Melawi Provinsi Kalimantan Barat
Cara pengolahan tumbuhan yang dimanfaatkan sebagai bahan pangan oleh masyarakat Desa Nanga Kebebu Kecamatan Nanga Pinoh Kabupaten Melawi

Proses terpenting agar bahan pangan dapat dimanfaatkan adalah cara pengolahan. Hasil penelitian menunjukkan masyarakat Desa Nanga Kebebu mengolah tumbuhan untuk dijadikan sebagai bahan pangan dengan cara langsung dikonsumsi sebanyak 33 jenis $(56,90 \%)$, direbus 10 jenis $(17,24 \%)$, ditumis 6 jenis $(10,34 \%)$ dan dibuat menjadi sambal 5 jenis $(8,62 \%)$, sedangkan cara pengolahan yang paling sedikit digunakan adalah dengan cara digoreng 2 jenis $(3,45 \%)$ dan dikeringkan 2 jenis $(3,45 \%)$. Pengolahan secara langsung umumnya dari jenis tumbuhan yang dimanfaatkan pada bagian buah. Cara pengolahan secara langsung dipilih oleh masyarakat karena buah tidak perlu pengolahan dan dapat langsung dikonsumsi. Penelitian ini sejalan dengan Nurchayati dan Ardiyansyah (2019) yang memperoleh 7 jenis tumbuhan dengan cara pengolahan secara langsung atau tanpa pengolahan sebagai sumber pangan oleh masyarakat Suku Using Kabupaten Banyuwangi dan penelitian Liza et al (2020) yang menemukan 28 jenis (41\%) tumbuhan tanpa melalui proses pengolahan yang dimanfaatkan oleh masyarakat Desa Jawai Laut Kecamatan Jawai Selatan Kabupaten Sambas.

Jenis tumbuhan yang direbus meliputi daun buas-buas yang disebut masyarakat daon bebuas (Premna serratifolia), enau atau aren (Arenga pinnata), jengkol atau jerin (Archidendron pauciflorum), keladi atau talas (Colocasia esculenta), kolang kalok atau kolang kaling (Litsea garciae), kemayau (Canarium odontophyllum) robong atau rebung atau bambu muda (Bambusa sp) dan

Ruwok atau rotan muda (Calamus rotang). Pandey et al (2016) menyatakan di India hasil hutan bukan kayu dikaitkan dengan kehidupan sosial-ekonomi dan budaya untuk memenuhi kebutuhan pangan. Masyarakat pedesaan mengolah tumbuhan sebagai bahan pangan dengan cara direbus dan dimakan langsung. Tumbuhan pangan sebagai hasil hutan bukan kayu berfungsi sebagai jaring pengaman mata pencaharian dan memiliki efek ganda dalam perekonomian dengan menghasilkan lapangan kerja dan pendapatan dalam kegiatan pengolahan makanan dan perdagangan. 
Pengolahan dan pengunaan tumbuhan pangan yang sederhana berkaitan dengan pengetahuan masyarakat tentang tumbuhan pangan yang umumnya diperoleh secara turun-temurun berdasarkan pada kebiasaan dan pengalaman seharihari. Pemanfaatan tumbuhan sumber pangan secara langsung bagi masyarakat merupakan cara yang paling efektif untuk memenuhi kebutuhan pangan karena dari segi biayanya yang murah dan tumbuhannya dapat diperoleh di lingkungan sekitar. Cara pengolahan melalui proses seperti ditumis, sambal, direbus dan digoreng karena tumbuhan tersebut hanya bisa dikonsumsi ketika sudah ada pengolahan yang baik sehingga dapat menjadi sumber makanan.

Cara penggunaan tumbuhan sebagai bahan pangan yang paling banyak yaitu dengan cara dimakan sebanyak 53 jenis (90\%), diminum (5\%) dan ditambahkan pada masakan sebagai bumbu masak (5\%). Cara penggunaan tumbuhan pangan dengan cara dimakan lebih banyak dibandingkan dengan cara diminum dan ditambahkan dalam masakan karena penggunaan dengan cara dimakan umumnya adalah dari golongan makanan pokok, sayur-sayuran dan buah-buahan. Jenis tumbuhan yang digunakan sebagai bumbu masak yang spesifik dari hutan adat Sebaju adalah daun sengkubak, yang berfungsi sebagai penyedap masakan dan mengganti penggunaan penyedap rasa kimia. Persentase cara pengolahan tumbuhan sebagai bahan pangan dari hutan adat Sebaju disajikan pada Gambar 5.

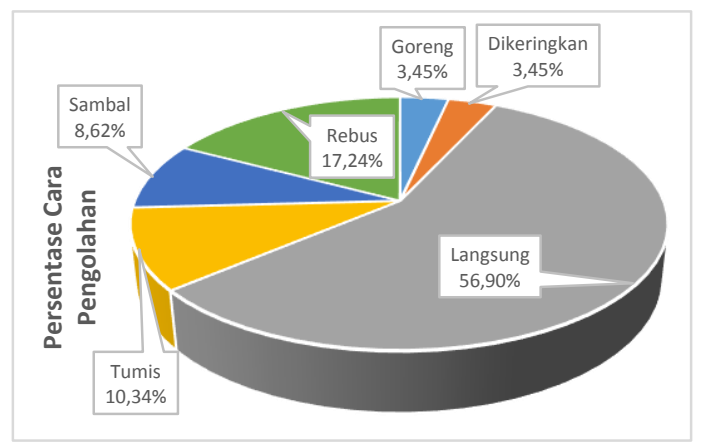

Gambar 5. Cara pengolahan tumbuhan yang digunakan sebagai bahan pangan dari Hutan Adat Sebaju Desa Nanga Kebebu Kecamatan Nanga Pinoh Kabupaten Melawi Provinsi Kalimantan Barat

Jenis pemanfaatan tumbuhan yang dimanfaatkan sebagai bahan pangan oleh masyarakat Desa

\section{Nanga Kebebu Kecamatan Nanga Pinoh \\ Kabupaten Melawi}

Berdasarkan jenis pemanfaatan tumbuhan sebagai bahan pangan oleh masyarakat Desa Nanga Kebebu dari hutan adat Sebaju meliputi buahbuahan, sayur-sayuran, umbi-umbian, minuman dan bumbu. Jenis pemanfaatan yang paling banyak adalah buah-buahan 40 jenis (67\%), sayur-sayuran 12 jenis (20\%), sedangkan yang paling sedikit adalah sebagai minuman 3 jenis (5\%), bumbu 3 jenis (5\%), dan umbi 2 jenis (3\%). Masyarakat sekitar hutan adat Sebaju Desa Nanga Kebebu menyatakan hutan memiliki potensi terbesar untuk menghasilkan buah-buahan, walaupun buah terkadang dapat dipanen dalam waktu sekitar satu tahun sekali, namun potensinya sangat banyak.

Jenis tumbuhan yang dimanfaatkan sebagai sayur ada 12 jenis (20\%). Sayur-sayuran yang dimanfaatkan masyarakat untuk keperluan seharihari adalah tumbuhan hasil hutan, selain dimanfaatkan untuk kebutuhan sendiri, sebagian dijual untuk memenuhi kebutuhan ekonomi. Tumbuhan pangan yang sering dimanfaatkan diantaranya pakuk pantai (Pletycenum $s p$ ), pakuk pidin (Stenochlaena palustris), rebung (Bambusa $s p$ ), dan kangkung (Ipomoea aquatic). Penelitian Nurhidayah et al (2015) menemukan 15 jenis sayuran yang dimanfaatkan sebagai bahan pangan di Desa Sebangun Kecamatan Sebawi Kabupaten Sambas.

Tumbuhan pangan hasil hutan yang sedikit digunakan adalah jenis tumbuhan sebagai minuman dan bumbu yaitu masing-masing 3 jenis (5\%). Jenis minuman yaitu asam maram (Elelodoxa conferta), aaren (Arenga pinnata) dan kelapa (Cocos nucifera). Jenis bumbu yaitu asam kandis (Garcinia bancana), daun salam (Syzygium polyanthum) dan daun micin atau daun Sengkubak (Pycnarrhena cauliflora Miers). Jenis tumbuhan dari umbi-umbian yaitu ubi kayu (Manihot utilissima) dan keladi (Colocasia esculenta). Bagian umbi keladi jarang dimanfaatkan karena memiliki rasa sedikit gatal. Sejalan dengan hasil penelitian ini, penelitian Juliana et al (2013) menyatakan umbi-umbian yang dimanfaatkan masyarakat Desa Pangkalan Buton Kecamatan Sukadana Kabupaten Kayong Utara hanya terdiri dari 2 jenis yaitu Ubi kayu (Manihot utilissima) dan Keladi (Colocasia esculenta). Ubi kayu ( $M$. utilisima) diolah dengan cara direbus atau digoreng, lalu daun mudanya dimanfaatkan untuk sayuran. 
Keladi (C. esculenta) umbi dan batangnya dimanfaatkan sebagai sayuran.

Status tumbuhnya tumbuhan yang digunakan sebagai bahan pangan dari hutan adat Sebaju Desa Nanga Kebebu Kecamatan Nanga Pinoh Kabupaten Melawi adalah tumbuh secara liar yaitu 34 jenis (59\%), dan tumbuh secara dibudidayakan 24 jenis (41\%). Hutan yang cukup luas membuat banyak sekali tumbuhan pangan yang tumbuh secara liar pada kawasan ini. Pemanfaatan tumbuhan sebagai bahan pangan sangat dirasakan masyarakat merupakan hal yang paling efektif untuk memenuhi kebutuhan hidup karena tumbuhan tersebut dapat diperoleh dengan mudah di lingkungan sekitar khususnya masyarakat yang tinggal di sekitar kawasan hutan adat Sebaju. Penelitian ini sejalan dengan hasil penelitian Dasman et al (2015) yang memperoleh $59,78 \%$ tumbuhan pangan yang tumbuh secara liar di sekitar hutan tembawang Desa Nanga Kompi Kecamatan Nanga Sayan Kabupaten Melawi. Powell et al (2015) menyatakan pangan hutan, termasuk produk dari pohon, jamur dan hewan, berkontribusi banyak dalam meningkatkan ketahanan pangan dengan menyediakan aksesibilitas, pangan siap pakai, terjangkau dan bergizi tinggi. Ickowitz et al (2016) menyatakan di daerah pedesaan dengan akses pasar yang buruk, hutan menjadi sumber penting makanan bergizi, pangan dari hutan memiliki banyak mikronutrien penting.

Vira et al (2015) menyatakan pendidikan dan kesadaran masyarakat pedesaan memainkan peranan penting dalam memberdayakan penduduk desa untuk ketahanan pangan dan pengelolaan hutan lestari. Pemanfaatan hutan dengan sistem berbasis pohon akan memberikan kontribusi pada tantangan tanpa kelaparan bagi masyarakat desa di sekitar hutan. Dhakal et al (2011) menyatakan di Nepal banyak rumah tangga pedesaan yang memanfaatkan sumber daya hutan untuk sumber pangan masyarakat dan ternak. Sunderland et al (2013) menyatakan pemanfaatan tumbuhan sumber pangan dari hutan secara langsung maupun tidak langsung mempunyai kaitan dalam upaya pelestarian dan pemanfaatan sumber daya hayati. Peran pemerintah dalam memberikan pemahaman yang lebih baik tentang hubungan makanan dan hutan, pengelolaan lanskap yang efektif dan tata kelola hutan adat yang lebih baik sangat diperlukan. Hutan dapat dikelola secara efektif untuk memberikan sumber makanan yang bergizi dan tetap berproduksi secara berkelanjutan.

\section{Kesimpulan}

Tumbuhan yang dimanfaatkan sebagai bahan pangan oleh masyarakat sekitar hutan adat Sebaju Desa Nanga Kebebu Kecamatan Nanga Pinoh Kabupaten Melawi Provinsi Kalimantan Barat sebanyak 58 jenis dengan jumah famili sebanyak 31 famili. Famili yang mendominasi adalah famili Anacardiaceae sebanyak 8 spesies, diikuti famili Arecaceae dan Moraceae sebanyak 5 spesies, famili Sapindaceae, Phyllanthaceae, Myrtaceae dan Fabaceae masing-masing sebanyak 3 spesies, dan famili lainnya masing-masing memiliki 1-2 spesies tumbuhan. Habitus tumbuhan yang digunakan sebagai bahan pangan adalah pohon sebanyak 40 jenis $(68,96 \%)$, herba sebanyak 8 jenis $(13,79 \%)$, perdu sebanyak 4 jenis $(6,89 \%)$ dan liana dan semak, masing-masing sebanyak 3 jenis $(5,17 \%)$. Bagian tumbuhan yang digunakan adalah buah yaitu sebanyak 44 jenis $(75,38 \%)$, daun 8 jenis $(13,79 \%)$ umbut 2 jenis $(3,45 \%)$, umbi 2 jenis $(3,45 \%)$, bunga 1 jenis $(1,72 \%)$, dan biji $1(1,72 \%)$. Cara pengolahan tumbuhan pangan adalah secara langsung yaitu 33 jenis $(56,90, \%)$, direbus 10 jenis $(17,24 \%)$, ditumis 6 jenis $(10,34 \%)$, dijadikan sambal 5 jenis $(8,62 \%)$, digoreng 2 jenis $(3,45 \%)$ dan dikeringkan 2 jenis $(3,45 \%)$. Cara penggunaan yaitu dimakan 53 jenis (90\%), diminum 3 jenis (5\%) dan ditambahkan pada masakan 3 jenis (5\%). Berdasarkan status tumbuhnya adalah tumbuh secara liar yaitu 34 jenis (59\%), dan tumbuh dibudidaya 24 jenis (41\%).

\section{Ucapan Terima Kasih}

Ucapan terima kasih diberikan kepada Fakultas Kehutanan Universitas Tanjungpura yang telah membiayai penelitian. Penelitian ini didanai oleh DIPA PNBP Fakultas Kehutanan dengan Surat Perjanjian Kontrak No 1164/UN22.7/PP/2020 tanggal 6 April 2020

\section{Referensi}

Birgantoro BA \& Nurrochmat DR (2007) Pemanfaatan sumberdaya hutan oleh masyarakat di KPH Banyuwangi utara. Jurnal Manajemen Hutan Tropika, 13(3):172-181 
http://journal.ipb.ac.id/index.php/jmht/article /view/2852

Dasman Y, Oramahi HA \& Sisillia L (2015) Tumbuhan sumber pangan yang dimanfaatkan oleh masyarakat sekitar hutan tembawang Desa Nanga Kompi Kecamatan Nanga Sayan Kabupaten Melawi. Jurnal Hutan Lestari, 3(2): $\quad 332 \quad-\quad 336$. https://jurnal.untan.ac.id/index.php/jmfkh/arti cle/view/10876

Dhakal B, Bigsby H, and Cullen R. (2011). Forests for Food Security and Livelihood Sustainability: Policy Problems and Opportunities for Small Farmers in Nepal. Journal of Sustainable Agriculture, 35:86-115 DOI: $10.1080 / 10440046.2011 .530903$

Deb D. (2017). Food and Nutrition from Forest: Relationships with Forest Ecological Status and Management System. Living Farms Press. India 65 pp. https://www.rosalux.de/fileadmin/user_uploa d/Food_and_Nutrition_from_Forest_Relationships_with_Forest_Ecological_Stat us_and_Management_System_public.pdf

Gupta A \& Mishra DK (2014). Food consumption pattern in rural India: a regional perspective. Journal of Economic \& Social Development 9(1): 1-16.

http://iesd.org.in/jesd/Journal\%20pdf/2014X-1\%20Food\%20Consumption.pdf

Ickowitz, A., Rowland, D., Powell, B., Salim, M.A. \& Sunderland, T. (2016) Forests, trees, and micronutrient-rich food consumption in Indonesia. PLoS ONE 11(5): e0154139. https://doi.org/10.1371/journal.pone.0154139

Irawan R, Oramahi HA, \& Hardiansyah G. (2020) Pemanfaatan tumbuhan sebagai bahan pangan di sekitar kawasan hutan Desa Sedahan Jaya Kecamatan Sukadana Kabupaten Kayong Utara. Jurnal Hutan Lestari, 8(3): 552-565 https://jurnal.untan.ac.id/index.php/jmfkh/arti cle/view/41730

DOI: http://dx.doi.org/10.26418/jhl.v8i3.41730

Juliana, Linda R, \& Mukarlina. (2013) Pemanfaatan tumbuhan yang berpotensi sebagai sumber pangan di Gunung Peramas Desa Pangkalan Buton Kecamatan Sukadana Kabupaten Kayong Utara. Jurnal Protobiont, 2(3):117121
DOI: http://dx.doi.org/10.26418/protobiont.v 2i3.3877

Krishnakumar J, Fox J \& Anitha V (2012) Nontimber forest products: livelihoods and conservation. Economic and Political Weekly XLVII (52): 132-139

https://www.epw.in/journal/2012/52/specialarticles/non-timber-forest-products.html

Liza, Oramahi HA, \& Sisillia L (2020). Jenis tumbuhan yang dimanfaatkan sebagai sumber pangan oleh masyarakat Jawai Laut Kecamatan Jawai Selatan Kabupaten Sambas, Jurnal Hutan Lestari 8(2): 315-324 DOI: http://dx.doi.org/10.26418/jhl.v8i2.400 52

Nurhidayah Y, Lovadi I, \& Linda R (2015) Tumbuhan berpotensi bahan pangan di Desa Sebangun Kecamatan Sebawi Kabupaten Sambas. Jurnal Protobiont, 4(1):151-159

DOI: http://dx.doi.org/10.26418/protobiont.v 4i1.9684

Nurchayati N \& Ardiyansyah F (2019) Pengetahuan lokal tanaman pangan dan pemanfaatannya pada masyarakat Suku Using Kabupaten Banyuwangi. Biotropika: Journal of Tropical Biology 07(1): 11-20 https://biotropika.ub.ac.id/index.php/biotropi $\mathrm{ka} /$ article/view/494

Nurhajijah, Linda R, \& Mukarlina (2017) Pemanfaatan tumbuhan pangan oleh suku Dayak Kanayatn di Kecamatan Ngabang Kabupaten Landak. Jurnal Protobiont, 6(3):817

DOI: http://dx.doi.org/10.26418/protobiont.v $6 \mathrm{i} 2.20796$

Pandey AK, Tripathi YC \& Kumar A (2016) Nontimber forest products (NTFPs) for sustained livelihoods: challenges and strategies. Research Journal of Forestry 10: 1-7. DOI: 10.3923/rjf.2016.1.7

Putri NH, Raksun A \& Mertha IG. (2018). Identifikasi tumbuhan paku sejati (Filicophyta) di kawasan hutan wisata Aik Nyet sebagai sumber belajar biologi. Jurnal Biologi Tropis, 18 (1): 104-108

DOI: http://dx.doi.org/10.29303/jbt.v18i1.734

Powell B, Maundu P, Kuhnlein HV \& Johns T. (2013) Wild foods from farm and forest in the East Usambara Mountains, Tanzania. 
Ecology of Food and Nutrition 52(6), 451478 https://doi.org/10.1080/03670244.2013.7681 22

Powell B, Thilsted SH, Ickowitz A, Termote C, Sunderland TCH \& Herforth A. (2015) Improving diets with wild and cultivated biodiversity from across the landscape. Food Security 7: 535-554. Food Sec. DOI 10.1007/s12571-015-0466-5

Pradityo T (2016) Etnobotani di kebun tembawang suku Dayak Iban Desa Sungai Mawang Kalimantan barat. Jurnal Media Konservasi, 21(2):183-198.

https://doi.org/10.29244/medkon.21.2.183198

Rahman K, Wardenaar E, \& Mariani Y (2019) Identifikasi jenis pemanfaatan tumbuhan obat di hutan tembawang oleh masyarakat Kelurahan Beringin Kecamatan Kapuas Kabupaten Sanggau. Jurnal Hutan Lestari, 7(1): 44-45

https://jurnal.untan.ac.id/index.php/jmfkh/arti cle/view/30996

Rowland D, Ickowitzi A, Powell B, Nasi R \& Sunderland T (2016) Forest foods and healthy diets: quantifying the contributions. Environmental Conservation 1- 13

DOI: $10.1017 / \mathrm{S} 0376892916000151$

Sugiyono (2013). Metode Penelitian Kuantitatif, Kualitatif dan R\&D. Bandung. Penerbit Alfabeta. $464 \mathrm{pp}$

http://cvalfabeta.com/product/metodepenelitian-kuantitatif-kualitatif-dan-rd-mpkk/

Suhanda AJ, Idham M, \& Anwari MS (2017). Studi etnobotani masyarakat Desa Raut Muara Kecamatan Sekayam Kabupaten Sanggau. Jurnal Hutan Lestari, 5(2): 183-190

https://jurnal.untan.ac.id/index.php/jmfkh/arti cle/view/19087

Sumarlin D, Dirhamsyah M \& Ardian H (2019). Identifikasi tumbuhan sumber pangan di hutan tembawang Desa Aur Sampuk Kecamatan Sengah Temila Kabupaten Landak. Jurnal Hutan Lestari, 4(1): 32-39 https://jurnal.untan.ac.id/index.php/jmfkh/arti cle/view/14481
Sunarti S, Rugayah \& Djarwaningsih T. (2007) Tumbuhan berpotensi bahan pangan di daerah Cagar Alam Tengkale. Jurnal Biodiversitas, 8(2): 88-91

https://biodiversitas.mipa.uns.ac.id/D/D0802/ D080202.pdf

Sunderland T, Powell B, Ickowitz A, Foli S, Vasquez MP, Nasi R, \& Padoch C. (2013). Food security and nutrition: The role of forests. CIFOR Press. Bogor. Indonesia. 11pp https://www.cifor.org/publications/pdf_files/ WPapers/DPSunderland1301.pdf

Toni P, Herawatiningsih R, \& Sisillia L (2017) Analisis vegetasi tumbuhan penghasil buahbuahan dalam kawasan tembawang Dusun Toho Raba Desa Rasan Kecamatan Ngabang Kabupaten Landak Jurnal Tengkawang, 7(1): 19-27

DOI: http://dx.doi.org/10.26418/jt.v7i1.2277 5

Vinceti B, Terte C, Ickowitz A, Powell B, Kehlenbeck K, \& Hunter D. (2013). The Contribution of Forests and Trees to Sustainable Diets. Sustainability 5:47974824, DOI: $10.3390 /$ su5114797

Vira B, Wildburger C, \& Mansourian S. (2015). Forests and Food: Addressing Hunger and Nutrition Across Sustainable Landscapes. Cambridge UK. Open Book Publishers. 275pp http://dx.doi.org/10.11647/OBP.0085

Wahyuni S, Manurung FT \& Kartikawati SM (2017) Identifikasi pohon penghasil buah pada kawasan hutan lindung Gunung PemancingGunung Ambawang Bukit Bendera Kecamatan Teluk Pakedai Kabupaten Kubu Raya. Jurnal Hutan Lestari, 5(2): 225-233 https://jurnal.untan.ac.id/index.php/jmfkh/arti cle/view/19106

Wiwik S, Kartikawati SM \& Anwari MS. (2019) Pemanfaatan bahan pangan masyarakat Desa Goa Boma Kecamatan Monterado Kabupaten Bengkayang. Jurnal Hutan Lestari, (1): 532540

https://jurnal.untan.ac.id/index.php/jmfkh/arti cle/view/32389 
Diba, F. et al. (2021). Jurnal Biologi Tropis, 21 (1): $52-64$

DOI: http://dx.doi.org/10.29303/jbt.v21i1.2317

Lampiran 1. Daftar tumbuhan yang digunakan sebagai bahan pangan dari hutan adat Sebaju Desa Nanga Kebebu Kecamatan Nanga Pinoh Kabupaten Melawi Provinsi Kalimantan Barat

\begin{tabular}{|c|c|c|c|c|c|c|c|c|c|}
\hline \multirow{2}{*}{ No } & \multirow{2}{*}{ Nama Lokal } & \multirow{2}{*}{$\begin{array}{l}\text { Nama } \\
\text { Indonesia }\end{array}$} & \multirow{2}{*}{ Nama Latin } & \multirow{2}{*}{ Famili } & \multirow{2}{*}{$\begin{array}{c}\text { Jenis } \\
\text { bahan } \\
\text { pangan }\end{array}$} & \multirow{2}{*}{$\begin{array}{c}\text { Bagian } \\
\text { yang } \\
\text { diguna } \\
\text { kan }\end{array}$} & \multirow{2}{*}{$\begin{array}{c}\text { Cara } \\
\text { Pengolahan }\end{array}$} & \multicolumn{2}{|c|}{$\begin{array}{c}\text { Status } \\
\text { Tumbuhan }\end{array}$} \\
\hline & & & & & & & & $\begin{array}{l}\text { Budi } \\
\text { daya }\end{array}$ & Liar \\
\hline 1 & Asam Ganis & Asam Kandis & Garcinia bancana & Clusiaceae & bumbu & Buah & dikeringkan & & $\checkmark$ \\
\hline 2 & Asam maram & Asam Maram & Elelodoxa conferta & Arecaceae & $\begin{array}{l}\text { Buah dan } \\
\text { minuman }\end{array}$ & Buah & $\begin{array}{l}\text { tanpa } \\
\text { pengolahan } \\
\text { /diolah }\end{array}$ & & $\checkmark$ \\
\hline 3 & $\begin{array}{l}\text { Belimin } \\
\text { Sapat }\end{array}$ & Belimbing & Averrhoa carambola & Oxalidaceae & Buah & Buah & Dimasak & $\checkmark$ & \\
\hline 4 & Belimin Ulu & $\begin{array}{l}\text { Belimbing } \\
\text { Wuluh }\end{array}$ & Averrhoa bilimbi & Oxalidaceae & Buah & Buah & Dimasak & $\checkmark$ & \\
\hline 5 & Buah Ubi & Ubi kayu & Manihot esculenta & Euphorbiaceae & umbi & Umbi & Direbus & $\checkmark$ & \\
\hline 6 & Daon Bebuas & $\begin{array}{l}\text { Daun Buas- } \\
\text { buas }\end{array}$ & Premna serratifolia & Verbenaceae & Sayur & Daun & Direbus & & $\checkmark$ \\
\hline 7 & Daon Ubai & Daun Salam & Syzygium polyanthum & Myrtaceae & bumbu & Daun & dikeringkan & & $\checkmark$ \\
\hline 8 & Daon Ubi & $\begin{array}{l}\text { Daun } \\
\text { Singkong }\end{array}$ & Manihot utilissima & Euphorbiaceae & Sayur & Daun & Dimasak & $\checkmark$ & \\
\hline 9 & Enau & Aren & Arenga pinnata & Arecaceae & Minuman & Buah & Direbus & & $\checkmark$ \\
\hline 10 & Engkuis & $\begin{array}{l}\text { Lengkeng } \\
\text { Lokal }\end{array}$ & Dimocarpus sp & Sapindaceae & Buah & Buah & $\begin{array}{l}\text { Langsung } \\
\text { dikonsumsi }\end{array}$ & $\checkmark$ & \\
\hline 11 & Entawok & Mentawa & Artocarpus anisophyllus & Moraceae & Buah & buah & $\begin{array}{l}\text { Langsung } \\
\text { dikonsumsi }\end{array}$ & & $\checkmark$ \\
\hline 12 & Genye & Genjer & Limnocharis flava & $\begin{array}{l}\text { Limnocharita } \\
\text { ceae }\end{array}$ & Sayur & Daun & Ditumis & & $\checkmark$ \\
\hline 13 & Gitok & Gitaan & Willughbeia angustifolia & Apocynaceae & Buah & Buah & $\begin{array}{l}\text { Langsung } \\
\text { dikonsumsi }\end{array}$ & & $\checkmark$ \\
\hline 14 & Jamu Aik & Jamu aik & Syzygium aqueum & Myrtaceae & Buah & buah & $\begin{array}{l}\text { Langsung } \\
\text { dikonsumsi }\end{array}$ & $\checkmark$ & \\
\hline 15 & Jamu Bol & Jamu bol & Syzygium malaccense & Myrtaceae & Buah & Buah & $\begin{array}{l}\text { Langsung } \\
\text { dikonsumsi }\end{array}$ & $\checkmark$ & \\
\hline 16 & $\begin{array}{l}\text { Jamu } \\
\text { Monyet }\end{array}$ & Jamu Monyet & Anacardium occidentale & Anacardiaceae & Buah & Buah & $\begin{array}{l}\text { Langsung } \\
\text { dikonsumsi }\end{array}$ & & $\checkmark$ \\
\hline 17 & Jerin & Jengkol & Archidendron pauciflorum & Fabaceae & Buah & Buah & Direbus & $\checkmark$ & \\
\hline 18 & Kangkong & Kangkung & Ipomoea aquatic & Convolvulaceae & Sayur & Daun & dimasak & $\checkmark$ & \\
\hline 19 & Kedondong & Kedondong & Spondias dulcis & Anacardiaceae & Buah & Buah & $\begin{array}{l}\text { Langsung } \\
\text { dikonsumsi }\end{array}$ & $\checkmark$ & \\
\hline 20 & Keladi & Talas & Colocasia esculenta & Araceae & Umbi & Umbi & Direbus & & $\checkmark$ \\
\hline 21 & Kelotok & Rambutan & Nephelium lappaceum & Sapindaceae & Buah & Buah & $\begin{array}{l}\text { Langsung } \\
\text { dikonsumsi }\end{array}$ & $\checkmark$ & \\
\hline 22 & Keluweh & Keluwih & Artocarpus camansi & Moraceae & Buah & Buah & $\begin{array}{l}\text { Langsung } \\
\text { dikonsumsi }\end{array}$ & & $\checkmark$ \\
\hline 23 & Kemantan & Kalimantan & Mangifera foetida & Anacardiaceae & Buah & Buah & $\begin{array}{l}\text { Langsung } \\
\text { dikonsumsi }\end{array}$ & & $\checkmark$ \\
\hline 24 & Kemayau & Kemayau & Canarium odontophyllum & Burseraceae & Buah & Buah & Direbus & & $\checkmark$ \\
\hline 25 & Kemuntin & Cengkodok & $\begin{array}{l}\text { Melastoma malabathri } \\
\text { chum }\end{array}$ & $\begin{array}{l}\text { Melastomata } \\
\text { ceae }\end{array}$ & Buah & Buah & $\begin{array}{l}\text { Langsung } \\
\text { dikonsumsi }\end{array}$ & & $\checkmark$ \\
\hline 26 & Keranyik & Asam Keranji & Dialium indum & Fabaceae & Buah & Buah & $\begin{array}{l}\text { Langsung } \\
\text { dikonsumsi }\end{array}$ & & $\checkmark$ \\
\hline 27 & Kolangkalok & Kalangkala & Litsea garciae & Lauraceae & Buah & Buah & Direbus & & $\checkmark$ \\
\hline 28 & Lanyau & Djuping & Pentaspadon motley Hook & Anacardiaceae & Buah & Buah & Dimasak & & $\checkmark$ \\
\hline 29 & Lensat & Langsat & Lansium domesticum & Meliaceae & Buah & Buah & $\begin{array}{l}\text { Langsung } \\
\text { dikonsumsi }\end{array}$ & $\checkmark$ & \\
\hline 30 & Linang & Jeramun & Nephelium $s p$ & Sapindaceae & Buah & buah & $\begin{array}{l}\text { Langsung } \\
\text { dikonsumsi }\end{array}$ & & $\checkmark$ \\
\hline
\end{tabular}


Diba, F. et al. (2021). Jurnal Biologi Tropis, 21 (1): $52-64$

DOI: http://dx.doi.org/10.29303/jbt.v21i1.2317

\begin{tabular}{|c|c|c|c|c|c|c|c|c|c|}
\hline \multirow[b]{2}{*}{ No } & \multirow[b]{2}{*}{ Nama Lokal } & \multirow{2}{*}{$\begin{array}{l}\text { Nama } \\
\text { Indonesia }\end{array}$} & \multirow[b]{2}{*}{ Nama Latin } & \multirow[b]{2}{*}{ Famili } & \multirow{2}{*}{$\begin{array}{c}\text { Jenis } \\
\text { bahan } \\
\text { pangan }\end{array}$} & \multirow{2}{*}{$\begin{array}{c}\text { Bagian } \\
\text { yang } \\
\text { diguna } \\
\text { kan }\end{array}$} & \multirow{2}{*}{$\begin{array}{c}\text { Cara } \\
\text { Pengolahan }\end{array}$} & \multicolumn{2}{|c|}{$\begin{array}{c}\text { Status } \\
\text { Tumbuhan } \\
\end{array}$} \\
\hline & & & & & & & & $\begin{array}{l}\text { Budi } \\
\text { daya }\end{array}$ & Liar \\
\hline 31 & Mango & Mangga & Mangifera indica & Anacardiaceae & Buah & Buah & $\begin{array}{l}\text { Langsung } \\
\text { dikonsumsi }\end{array}$ & $\checkmark$ & \\
\hline 32 & Marau & Buah Rotan & Daemonorops draco & Arecaceae & Buah & Buah & $\begin{array}{l}\text { Langsung } \\
\text { dikonsumsi }\end{array}$ & & $\checkmark$ \\
\hline 33 & Mawang & Mawang & Mangifera $s p$ & Anacardiaceae & Buah & buah & $\begin{array}{l}\text { Langsung } \\
\text { dikonsumsi }\end{array}$ & & $\checkmark$ \\
\hline 34 & Mengkudu & Mengkudu & Morinda citrifolia & Rubiaceae & Sayur & daun & Dimasak & & $\checkmark$ \\
\hline 35 & Nanas & Nanas & Ananas comosus & Bromeliaceae & Buah & Buah & $\begin{array}{l}\text { Langsung } \\
\text { dikonsumsi }\end{array}$ & $\checkmark$ & \\
\hline 36 & Nangkok & Nangka & Artocarpus heterophyllus & Moraceae & Buah & Buah & $\begin{array}{l}\text { Langsung } \\
\text { dikonsumsi }\end{array}$ & $\checkmark$ & \\
\hline 37 & Nerian & Durian & Durio zibethinus & Bombacaceae & Buah & Buah & $\begin{array}{l}\text { Langsung } \\
\text { dikonsumsi }\end{array}$ & $\checkmark$ & \\
\hline 38 & Nyio & Kelapa & Cocos nucifera & Arecaceae & Minuman & Buah & $\begin{array}{l}\text { Langsung } \\
\text { dikonsumsi }\end{array}$ & $\checkmark$ & \\
\hline 39 & Pakuk Pantai & Pakis Hijau & Pletycenum sp & Polypodiaceae & Sayur & Daun & Dimasak & & $\checkmark$ \\
\hline 40 & Pakuk Pidin & Pakis & Stenochlaena palustris & Blechnaceae & Sayur & Daun & Dimasak & & $\checkmark$ \\
\hline 41 & Pekawai & Pekawai & Durio kuteijeinsis & Bombacaceae & Buah & Buah & $\begin{array}{l}\text { Langsung } \\
\text { dikonsumsi }\end{array}$ & $\checkmark$ & \\
\hline 42 & Petai & Petai & Parkia speciosa & Fabaceae & Sayur & Biji & Dimasak & $\checkmark$ & \\
\hline 43 & Pisang & Pisang & Musa parasidica & Musaceae & Buah & Buah & $\begin{array}{l}\text { Langsung } \\
\text { dikonsumsi }\end{array}$ & $\checkmark$ & \\
\hline 44 & Remai & Rambai & Baccaurea motleyana & Phyllanthaceae & Buah & Buah & $\begin{array}{l}\text { Langsung } \\
\text { dikonsumsi }\end{array}$ & $\checkmark$ & \\
\hline 45 & Robong & Bambu muda & Bambusa sp & Poaceae & Sayur & Umbut & Direbus & & $\checkmark$ \\
\hline 46 & Rokam & Rukem & Flacourtia rukam & Salicaceae & Buah & Buah & $\begin{array}{l}\text { Langsung } \\
\text { dikonsumsi }\end{array}$ & & $\checkmark$ \\
\hline 47 & Ruwok & Rotan Muda & Calamus rotang & Arecaceae & Sayur & Umbut & Direbus & & $\checkmark$ \\
\hline 48 & Sata & Gandaria & $\begin{array}{l}\text { Bouea macrophylla } \\
\text { Griffith }\end{array}$ & Anacardiaceae & Buah & Buah & $\begin{array}{l}\text { Langsung } \\
\text { dikonsumsi }\end{array}$ & & $\checkmark$ \\
\hline 49 & Semplam & Asam Pelam & Mangifera sp & Anacardiaceae & Buah & Buah & $\begin{array}{l}\text { Langsung } \\
\text { dikonsumsi }\end{array}$ & $\checkmark$ & \\
\hline 50 & Sengkuang & Sengkuang & Dracontomelondao & Spondiaceae & Buah & Buah & $\begin{array}{l}\text { Langsung } \\
\text { dikonsumsi }\end{array}$ & & $\checkmark$ \\
\hline 51 & Sengkubak & Daun Micin & $\begin{array}{l}\text { Pycnarrhena cauliflora } \\
\text { Miers }\end{array}$ & $\begin{array}{l}\text { Menisperma } \\
\text { ceae }\end{array}$ & bumbu & daun & $\begin{array}{l}\text { Langsung } \\
\text { dikonsumsi }\end{array}$ & & $\checkmark$ \\
\hline 52 & Sibong & Kecom brang & Etlingera elatior & Zingiberaceae & Sayur & Bunga & Dimasak & & $\checkmark$ \\
\hline 53 & Sukon & Sukun & Artocarpus altilis & Moraceae & Buah & Buah & Dimasak & $\checkmark$ & \\
\hline 54 & Sungkup & Manggis & Garcinia mangostana & Clusiaceae & Buah & Buah & $\begin{array}{l}\text { tanpa } \\
\text { pengolahan }\end{array}$ & & $\checkmark$ \\
\hline 55 & Tamang & Bengkinang & Elaeocarpus glaber B1. & Elaeocarpaceae & Buah & Buah & $\begin{array}{l}\text { tanpa } \\
\text { pengolahan }\end{array}$ & & $\checkmark$ \\
\hline 56 & Tampui & Tampui & Baccaurea macrocarpa & Phyllanthaceae & Buah & Buah & $\begin{array}{l}\text { tanpa } \\
\text { pengolahan }\end{array}$ & & $\checkmark$ \\
\hline 57 & Tebedak & Cempedak & Artocarpus integer & Moraceae & Buah & Buah & $\begin{array}{l}\text { tanpa } \\
\text { pengolahan }\end{array}$ & $\checkmark$ & \\
\hline 58 & Tengkawang & Tengka wang & Shorea & $\begin{array}{l}\text { Dipterocarpa } \\
\text { ceae }\end{array}$ & Buah & Buah & dimasak & & $\checkmark$ \\
\hline
\end{tabular}

